\title{
Advances in Modeling the Immune Microenvironment of Colorectal Cancer
}

\author{
Paul Sukwoo Yoon ${ }^{1 t}$, Nuala Del Piccolo ${ }^{2 \dagger}$, Venktesh S. Shirure ${ }^{2}$, Yushuan Peng ${ }^{2}$, \\ Amanda Kirane ${ }^{1}$, Robert J. Canter ${ }^{1}$, Ryan C. Fields ${ }^{3}$, Steven C. George ${ }^{2}$ \\ and Sepideh Gholami ${ }^{1 *}$ \\ ${ }^{1}$ Department of Surgery, University of California, Davis, Sacramento, CA, United States, ${ }^{2}$ Department of Biomedical \\ Engineering, University of California, Davis, Davis, CA, United States, ${ }^{3}$ Department of Surgery, The Alvin J. Siteman Cancer \\ Center, Washington University School of Medicine, St. Louis, MO, United States
}

OPEN ACCESS

Edited by:

Benjamin Frey,

University Hospital Erlangen, Germany

Reviewed by:

Nathalie Britzen-Laurent, University Hospital Erlangen, Germany Laura Bracci, National Institute of Health (ISS), Italy

*Correspondence: Sepideh Gholami sgholami@ucdavis.edu

${ }^{t}$ These authors have contributed equally to this work

Specialty section: This article was submitted to

Cancer Immunity and Immunotherapy,

a section of the journal

Frontiers in Immunology

Received: 05 October 2020 Accepted: 29 December 2020 Published: 10 February 2021

Citation:

Yoon PS, Del Piccolo N, Shirure VS, Peng Y, Kirane A, Canter RJ, Fields RC, George SC and Gholami S (2021) Advances in Modeling the Immune Microenvironment of Colorectal Cancer.

Front. Immunol. 11:614300. doi: 10.3389/fimmu.2020.614300
Colorectal cancer $(\mathrm{CRC})$ is the third most common cancer and second leading cause of cancer-related death in the US. CRC frequently metastasizes to the liver and these patients have a particularly poor prognosis. The infiltration of immune cells into CRC tumors and liver metastases accurately predicts disease progression and patient survival. Despite the evident influence of immune cells in the CRC tumor microenvironment (TME), efforts to identify immunotherapies for CRC patients have been limited. Here, we argue that preclinical model systems that recapitulate key features of the tumor microenvironment-including tumor, stromal, and immune cells; the extracellular matrix; and the vasculature-are crucial for studies of immunity in the CRC TME and the utility of immunotherapies for CRC patients. We briefly review the discoveries, advantages, and disadvantages of current in vitro and in vivo model systems, including 2D cell culture models, 3D culture systems, murine models, and organ-on-a-chip technologies.

Keywords: colorectal cancer, tumor microenvironment, cancer immunology, tissue engineering, organ-on-achip (OOC)

\section{INTRODUCTION}

In the US, colorectal cancer (CRC) is the third most common cancer and second leading cause of cancer-related death (1). CRC is largely asymptomatic until it has progressed to advanced stages (2), with 5 year survival rates of $90 \%$ and $14 \%$ for localized and metastatic cases, respectively (1). Population-wide screening campaigns in the last two decades have led to earlier diagnoses and boosted the overall 5 year survival rate to $\sim 65 \%$ (1). Due to anatomical proximity, CRC often metastasizes to the liver: $20 \%-25 \%$ of patients present with colorectal liver metastases (CRLM) at initial diagnosis and 50-60\% of CRC patients will develop CRLM at some point (2-4). Hepatectomy is currently the best course of action for CRLM patients, offering a 5 year survival rate of up to $60 \%$ (3-5). Unfortunately, only $20 \%-25 \%$ of CRLM patients are eligible for resection at time of diagnosis, leaving a large majority of patients to succumb to progressive metastatic cancer $(3,5)$.

Recent research has demonstrated the role of immunity on CRC progression, prognosis, and response to therapy. For example, immune cell infiltration into tumors correlates with clinical outcomes: T cells (6-10), Tregs (11), and NK cells (10) in primary CRC or CRLM lesions correlate 
with better prognoses, while the presence of tumor-associated macrophages (TAMs) has been alternately associated with pro$(12,13)$ and anti-tumor $(13-15)$ effects. In 2006, Galon and colleagues introduced the ImmunoScore. This measure of the density of immune cells in the invasive margin and core of a lesion (9, 16-18) provides more accurate predictions of recurrence, overall survival, and disease-free survival than traditional TNM staging for both CRC $(7,16,18)$ and CRLM patients $(6,8,11,16)$.

Based on ImmunoScore's prognostic success, clinicians are actively pursuing immunotherapies for CRC and CRLM patients. Checkpoint blockade therapies have shown particular promise for mismatch repair deficient (dMMR)/microsatellite instabilityhigh (MSI-H) CRC tumors (19-21). In a 2015 Phase II clinical trial, dMMR/MSI-H patients treated with pembrolizumab (PD-1 inhibitor) exhibited a $40 \%$ response rate and $78 \%$ 12-month progression free survival (22); the FDA approved this course of treatment in 2017 (19). More recent work has probed the utility of combining nivolumab (PD-1 inhibitor) with ipilimumab (CTLA-4 inhibitor) (23). Results from this Phase II trial are still maturing, but preliminary results suggest a response rate as high as $55 \%(19,23)$. Unfortunately, only $15 \%$ of CRC tumors are classified as dMMR/MSI-H (19), and there are currently no immunotherapies available to the remaining $85 \%$ of CRC patients. Pre-clinical work addressing this gap is focused on adoptive cell therapies, vaccines, immunostimulatory cytokines, and combinations thereof, and early studies have produced promising results (19-21).

The development of more efficacious cancer therapeutics is hindered by the limitations of current preclinical model systems, which do not recapitulate the whole tumor microenvironment (TME) (Table 1) $(24,25)$. The TME is crucial for investigating tumor-immune cell crosstalk, modeling tumor heterogeneity within and between patients, recapitulating events in the metastatic cascade, and simulating responses to therapeutics (24-28). 2D in vitro models of cells growing in tissue culture plates lend themselves to the study of tumor growth and cell migration, but lack complex tissue features like the vasculature and extracellular matrix (ECM) $(24,25,28-31)$. In $3 \mathrm{D}$ in vitro models, multiple cell types can be co-cultured in ECM scaffolds, enabling the study of cell-cell interactions and nutrient/waste transport over small distances; however, these models lack key biomechanical features of the TME, including vascular and interstitial perfusion $(24,25,28-31)$. Animal models are capable of simulating the dynamic, multi-cellular/organ nature of the TME, but are expensive, difficult to manipulate, and limited in their ability to recreate human immunobiology (24, 32-34).

TABLE 1 | Advances in modeling colorectal cancer

\begin{tabular}{|c|c|c|c|}
\hline Model & Application & Advantages & Disadvantages \\
\hline $\begin{array}{l}\text { 2D In vitro } \\
\text { Culture plate }\end{array}$ & $\begin{array}{l}\text { - Adhesion } \\
\text { - Gene expression } \\
\text { - Drug screening }\end{array}$ & \multirow[t]{2}{*}{$\begin{array}{l}\text { - Simple } \\
\text { - } \text { Low cost } \\
\text { - High throughput }\end{array}$} & \multirow[t]{2}{*}{$\begin{array}{l}\text { - Low predictive power } \\
\text { - Lack of native architecture } \\
\text { - Loss of tumor heterogeneity }\end{array}$} \\
\hline Wound healing & - Migration & & \\
\hline $\begin{array}{l}\text { 3D In vitro } \\
\text { Organoid/ } \\
\text { Spheroid }\end{array}$ & $\begin{array}{l}\text { - } \text { Proliferation } \\
\text { - } \text { Migration } \\
\text { - } \text { Gene expression } \\
\text { - } \text { Drug screening }\end{array}$ & \multirow[t]{2}{*}{$\begin{array}{l}\text { - Retain native tumor geometry } \\
\text { - Cell-cell/ECM interaction } \\
\text { - Tumor heterogeneity }\end{array}$} & \multirow[t]{2}{*}{$\begin{array}{l}\text { - } \text { Avascular } \\
\text { - High cost } \\
\text { - Low scalability } \\
\text { - Low reproducibility }\end{array}$} \\
\hline Co-culture & $\begin{array}{l}\text { - } \text { Stromal crosstalk } \\
\text { - } \text { Immune crosstalk }\end{array}$ & & \\
\hline $\begin{array}{l}\text { In vivo } \\
\quad \text { Patient-derived xenografts }\end{array}$ & \multirow{3}{*}{$\begin{array}{l}\text { - } \text { Proliferation } \\
\text { - } \text { Migration } \\
\text { - Invasion } \\
\text { - Angiogenesis } \\
\text { - } \text { Gene expression } \\
\text { - } \text { Drug screening }\end{array}$} & - Tumor heterogeneity & $\begin{array}{l}\text { - High cost } \\
\text { - Laborious } \\
\text { - Low predictive power } \\
\text { - Immunocompromised } \\
\text { - Limited metastasis }\end{array}$ \\
\hline Humanized mice & & $\begin{array}{l}\text { - Tumor microenvironment } \\
\text { - Tumor heterogeneity } \\
\text { - Immunocompetent }\end{array}$ & $\begin{array}{ll}\text { - } & \text { High cost } \\
\text { - } & \text { Laborious } \\
\text { - } & \text { Incomplete immune function } \\
\text { - } & \text { Engraftment difficulties }\end{array}$ \\
\hline Genetically engineered mice & & $\begin{array}{l}\text { - Tumor microenvironment } \\
\text { - Tumor heterogeneity } \\
\text { - Immunocompetent } \\
\text { - } \quad \text { Natural disease progression }\end{array}$ & $\begin{array}{l}\text { - High cost } \\
\text { - Laborious } \\
\text { - Time consuming }\end{array}$ \\
\hline Organ-on-a-chip & $\begin{array}{l}\text { - } \text { Proliferation } \\
\text { Migration } \\
\text { - Intravasation } \\
\text { Extravasation } \\
\text { - Invasion } \\
\text { - } \text { Angiogenesis } \\
\text { - } \quad \text { Stromal crosstalk } \\
\text { - Immune crosstalk } \\
\text { - } \quad \text { Gene expression } \\
\text { - } \quad \text { Drug screening }\end{array}$ & $\begin{array}{l}\text { - Tumor microenvironment } \\
\text { - } \text { Tumor heterogeneity } \\
\text { - } \text { Vascular } \\
\text { - Hydrodynamic properties } \\
\text { - Biochemical gradient } \\
\text { - } \text { Precise control } \\
\text { - } \text { Easy visualization }\end{array}$ & $\begin{array}{l}\text { - Lack of standardization } \\
\text { - High cost } \\
\text { - Laborious } \\
\text { - Low reproducibility }\end{array}$ \\
\hline
\end{tabular}


Model systems that combine tissue engineering with microfluidic technology represent a new frontier for the study of cancer development, progression, immunity, and metastasis. Dubbed "organ-on-a-chip" (OOC) systems, these models incorporate many features of the TME, including multiple cell types, matrix components, biochemical cues, spatiotemporal distribution of soluble mediators and oxygen, and perfusable vascular networks $(24,26,35-37)$. Thus, OOC platforms offer great potential as a preclinical tool for precision therapy. This review will highlight recent advances in the utility of OOC devices to model immunity in the CRC/CRLM TME and compare this work with conventional model systems (Figure 1A).

\section{TWO-DIMENSIONAL (2D) CULTURES}

Cell cultures in 2D (Figure 1A) are a standard and well-established model system because they are simple, inexpensive, and easy to manipulate, and enable imaging with high spatiotemporal resolution (Table 1) $(24,31)$. 2D cultures rely on cells adhering to a flat surface-generally a flask or plate-which does not reflect the natural 3D architecture of tissues or tumors. Furthermore, cells in $2 \mathrm{D}$ cultures receive relatively uniform and often excessive levels of oxygen, nutrients, and growth factors, compromising their ability to faithfully capture the in vivo TME (28-31). Despite these drawbacks, 2D experiments have revealed multiple mechanisms driving the behavior of epithelial sheets of cells (30) and epithelialderived tumors like CRC and CRLM (40-50).

2D cultures are conducive to studies of tumor-immune cell crosstalk in the TME. For example, $2 \mathrm{D}$ in vitro systems have been used to examine the role of the CRC TME's atypically high number of macrophages, a topic of active debate. These studies show that macrophages differentiate towards an M2-like phenotype in response to tumor cells or tumor cell-conditioned media (51-55) and migrate towards tumor cells $(54,55)$. TAMs in CRC have also been shown to modify the tumor cell response to chemotherapy $(56,57)$; support tumor cell proliferation, migration, and invasion (53-55); and limit tumor cell survival in a cell contact-dependent manner (13). Additionally, Yu and coauthors showed that mast cells migrate towards CRC tumor cellconditioned media in a Transwell assay and that co-culture of mast and tumor cells increases tumor cell proliferation; the results of these $2 \mathrm{D}$ culture experiments were verified in a $3 \mathrm{D}$ spheroid model (58). Studies with primary patient samples have demonstrated i) an HLA-mediated $\mathrm{T}$ cell response to the survivin protein in CRC tumor cells (59), and ii) NK cell cytotoxicity directed against CRC tumor cells following immune cell activation or tumor cell priming (60).

\section{THREE-DIMENSIONAL (3D) CULTURES}

3D cell cultures (Figure 1A) are comprised of cells distributed in synthetic or naturally-occurring scaffolds or hydrogels to mimic in vivo tissue architecture and can be cultured under static or perfused conditions (28-30). Compared to 2D cell culture systems, 3D in vitro systems more accurately model in vivo biochemical factor distribution and transport $(28,30)$; cell morphology, polarity, and gene expression (61-66); heterogeneity in cell types $(62,64,67)$; and sensitivity to cancer therapeutics $(61,64,67,68)$. This accuracy is more pronounced under perfused culture conditions (61, 67-69) (Table 1). The challenges facing 3D cell culture systems include: i) uncertainty introduced by the underdefined, variable composition of popular scaffold materials (including the gold standard Matrigel); ii) the absence of vascular flow, which is responsible for cancer cell dissemination, trafficking of some immune cells, and delivery of therapeutics; iii) the inability to replicate the long-range interactions between tumors and other organs in the body that govern metastasis and the immune response $(24,29,35,70)$; and iv) limited reproducibility, scalability, and ease of use.

A handful of recent reports demonstrate the utility of 3D models systems for the study of immunity in the CRC TME. In a 2018 paper, Dijkstra et al. co-cultured organoids from dMMR CRC patients with autologous peripheral blood lymphocytes (71). In this novel culture system, the team generated patient-specific, cancer-reactive $\mathrm{T}$ cells from 4 of 8 patients, characterized the specificity of $\mathrm{T}$ cells for tumor versus healthy tissue, and measured the efficiency of $\mathrm{T}$ cell mediated tumor cell killing. A 2019 report by Courau and colleagues demonstrated that primary $\mathrm{T}$ and NK cells infiltrate into cell line-derived CRC spheroids, where they kill tumor cells and degrade the 3D structure of the spheroid, and that these effects can be enhanced by stimulating the immune response with IL-15 plus anti-NKG2D and/or anti-MICA/B antibodies (72). The authors also showed that stimulation of the immune response is necessary for infiltration of autologous $\mathrm{T}$ and NK cells into patient-matched CRC spheroids. Another recent study found that CAR-NK-92 cells engineered to recognize the universal antigen EPCAM, the neoantigen EGFRvIII, or the tumor-associated antigen FRIZZLED can identify and lyse cells in murine- and patient-derived normal colon and CRC organoids, but the effects are reduced by limited immune cell infiltration into organoids (73). Further, a 2019 report showed that primary CRC samples cultured under perfused conditions retained native tissue architecture, tumor cell density, and immune and stromal cell viability better than samples cultured under static conditions (69).

\section{IN VIVO MODELS}

In vivo models (Figure 1A) are integral tools in cancer research because they recapitulate several features of the TME not available in in vitro models, including vascular flow and communication between the tumor and distant organs (74-79). There are five types of mouse models of cancer: 1) xenograft, 2) allograft, 3) patientderived xenograft (PDX), 4) humanized, and 5) genetically modified mouse (GEMM). Though murine models are labor intensive, expensive, low-throughput, and susceptible to cross-species incompatibilities, they have produced numerous insights into CRC response to drug treatment $(76,77,80-87)$ and metastasis (85, 88-90) (Table 1).

Though transplant mouse models (xenograft, allograft, and PDX) accurately replicate the response to therapeutics 
A Tumor Models Types and Applications
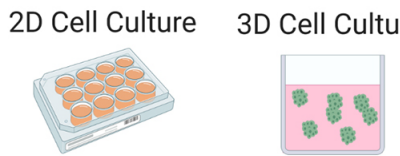

Murine Model

Organ-on-Chip

$\begin{array}{lll}\text { - Adhesion } & \text { - Proliferation } & \text { - Proliferation } \\ \text { - Migration } & \text { - Migration } & \text { - Migration } \\ \text { - Gene expression } & \cdot \text { Stromal crosstalk } & \text { - Invasion } \\ \text { - Drug screening } & \cdot \text { Immune crosstalk } & \text { - Angiogenesis } \\ & \cdot \text { Gene expression } & \text { - Gene expression } \\ & \cdot \text { Drug screening } & \text { - Drug screening }\end{array}$

**Bolded applications are particularly well suited for the model
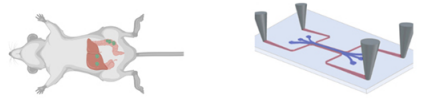

B
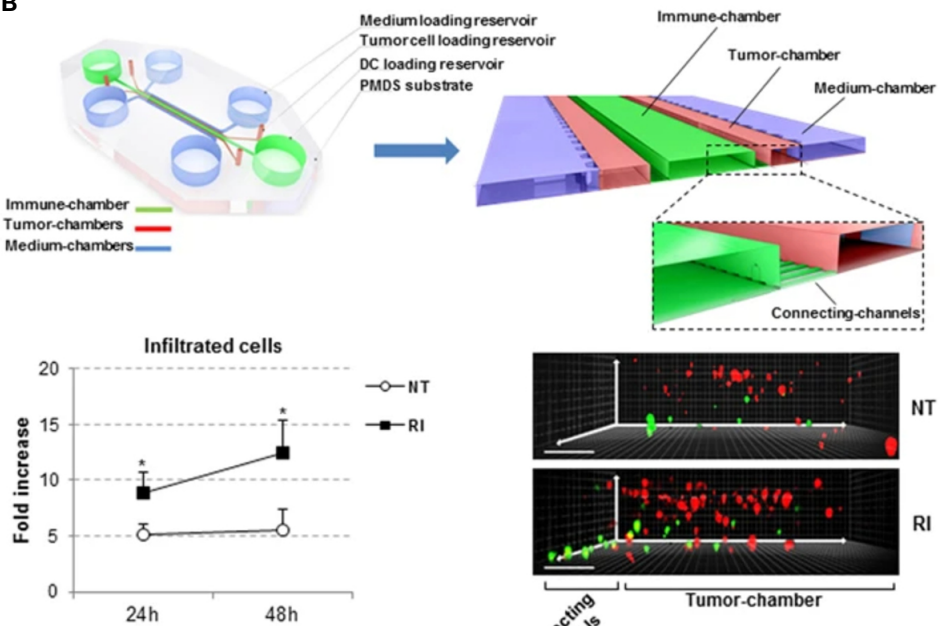

- Migration

- Intravasation

- Extravasation

- Invasion

- Angiogenesis

- Stromal crosstalk

- Immune crosstalk

- Gene expression

- Drug screening

Tumor-chambers

C
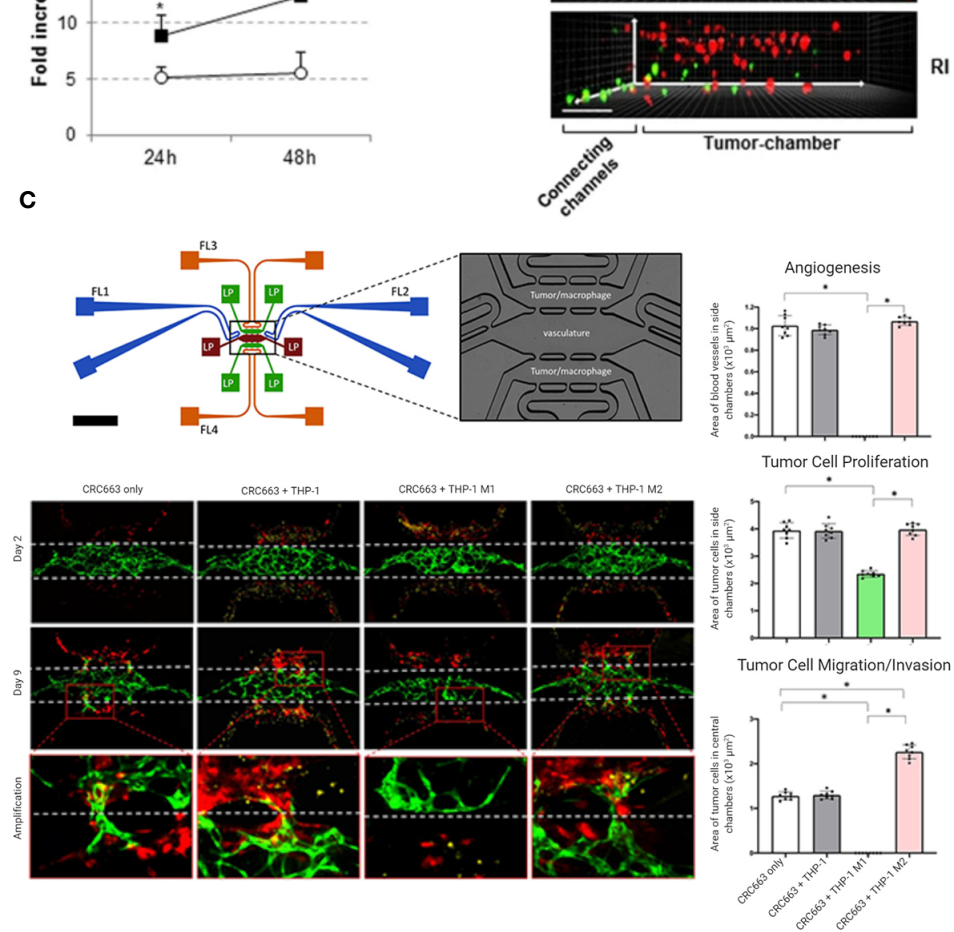

FIGURE 1 | (A) Colorectal liver metastasis models. Bolded applications are particularly well suited for the model. Even in the same category of model, constituent models can vary greatly, based on design, method, and study goals. (B, C) Colorectal cancer (CRC) "organ-on-a-chip" (OOC) platforms can model the immune response to tumors. (B) CRC cells (red) and IFN-DCs (green) are cultured in an OOC device (see cartoon) to simulate immune crosstalk. IFN-DCs migrate towards and phagocytose CRC cells following treatment with interferon- $\alpha$ and romidepsin. Images have been adapted from Parlato et al's 2017 Scientific Reports article (38). (C) M1 and M2 macrophages (red) cultured with CRC cell lines (not shown) in a vascularized OOC platform (vessels shown in green) display anti- and pro-tumor effects, respectively. Figure was originally published in Bi et al's 2020 Integrative Biology report (39). 
$(76,77,80-84)$, they struggle to retain the genetic and cellular features of native tumors $(76,79)$, recreate the metastatic cascade (with the possible exception of orthotopic transplant models) (89), and mimic the immune response to a tumor (note that xenograft and PDX models are both necessarily immunocompromised to enable inoculation with human cell lines and primary human tumor cells, respectively) $(76,79)$. Hence, humanized mouse models and GEMMs are more useful for studies of immunity in the TME. Humanized mice are generated by engrafting specific mouse strains with human leukocytes (hematopoietic stem cells or peripheral blood mononuclear cells). These mice produce a human immune response and are available commercially $(91,92)$, but sometimes suffer from xenoreactive complications and do not mount a full humoral immune response (74). In the context of CRC, humanized mouse models have been used to study tumor response to checkpoint blockade therapies $(93,94)$. In a 2015 report, humanized mice engrafted with a CRC cell line and treated with urelumab (CD137 inhibitor), nivolumab (PD-1 inhibitor), or a combination of the two demonstrated limited tumor growth and high infiltration of tumors by lymphocytes (93). Capasso and co-authors created humanized PDX mouse models by implanting patient-derived MSI-H or microsatellite stable (MSS) tumor cells and then treated the mice with nivolumab (PD-1 inhibitor) (94). Mice bearing MSI-H tumors showed high $\mathrm{T}$ cell infiltration into tumors and inhibited tumor growth compared to mice bearing MSS tumors; these results match clinical observations.

GEMMs are created by activating or deactivating specific genes using genome editing technology $(75,89,95)$. These models retain a natural murine immune system; can simulate the natural development of CRC tumors from adenoma to carcinoma to metastasis $(85,88,90)$; and can reproduce tumor response to therapy $(75,85-87,95)$. Drawbacks to GEMMs include that they are time consuming and expensive to generate and characterize, and have a long time course of disease progression compared to other model systems (75, 89, 95). Tauriello and colleagues reported a set of GEMMs with mutations in one or more of the CRC-associated genes $A p c$, Kras, Tgfbr2, and Trp53 (87); these models recreate many features of the human TME, including well-differentiated cancer cells, desmoplasia, and metastasis to the lung and liver. In subsequent experiments, the research team transplanted organoids from these CRC GEMMs into C57BL/6J mice to produce a model of advanced disease characterized by immune cell exclusion, increased TGF $\beta$ activity, and metastasis. Treatment with galunisertib (TGFBR1 inhibitor) reduced tumor growth and metastasis, increased immune cell infiltration and activation, and rendered tumors more responsive to anti-PD-L1 immunotherapy. Kostic et al. used a CRC GEMM model with a mutation in one copy of the $A p c$ gene to explore the idea that the microbiome plays a role in CRC development (96). Mice were fed either a Streptococcus species or Fusobacterium nucleatum. The latter bacteria is found at higher levels in CRC tumor tissue than healthy colon tissue; indeed, mice fed F. nucleatum developed tumors more quickly and these tumors were infiltrated with high levels of pro-tumor immune cells, including myeloid-derived suppressor cells, granulocytes, neutrophils, TAMs, and M2-like macrophages. Some CRC cases are associated with colitis, a state of constant inflammation in the colon; colitis can be modeled in mice through treatment with azoxymethane and/or dextran sodium sulfate. Through comparisons of wild-type and knockout GEMM colitis mouse models, researchers have demonstrated the critical role of p53 (97), IL-6 and Stat3 (98), TLR4 (99), Pycard, Casp1, and Nlrp3 (100), and Nod1 (101) on tumor formation and growth; all of these factors are implicated in regulation of the immune response.

\section{ORGAN-ON-A-CHIP MODELS}

OOC models (Figure 1A) utilize microfluidic technology and tissue engineering to mimic and monitor dynamic 3D tissue microenvironments, including epithelial barriers, parenchymal tissues, perfused microvasculature, multiple organ interactions, and the immune response $(24,37)$. An OOC platform consists of an interconnected series of 3D channels and chambers filled with cells suspended in hydrogels. The geometry of these channels and chambers can be precisely selected to match a variety of tissue architectures and mechanical forces, has a scale of tens to hundreds of microns, and is carved into an optically clear polymer using microfabrication or $3 \mathrm{D}$ printing $(24,102)$. Strengths of OOC systems include the ability to incorporate multiple human cell types at physiologically-relevant ratios; control hydrogel composition and spatial distribution; customize the physiochemical properties of the tissue microenvironment; and image tissues with high spatiotemporal resolution. Drawbacks of this emerging technology include difficulties transferring technology between labs, a lack of standardized benchmarks of success, and low-throughput experiments (Table 1).

Recent studies in CRC OOC models have successfully reproduced disease progression (103-106), immunity $(38,107-$ 109), metastasis (110-112), and response to therapy (38, 103, 105-107, 110, 113). Biochemical gradients of growth factors, cytokines, and chemokines influence cell migration, tissue phenotype, and angiogenesis in the TME (114), and can be established, monitored, and perturbed using OOC technologies (24, 114-116). Emerging methods also enable the manipulation of hypoxia in OOC devices $(117,118)$; this property regulates gene transcription and alters physiological and pathological immunity $(119,120)$. Our group has also pioneered methods to vascularize tissues, including CRC, in OOC devices $(39,103$, $106,113,121,122)$. These blood vessel networks self-assemble when endothelial cells and stromal cells are mixed, suspended in hydrogels, and cultured under perfusion conditions. These microvasculature models mimic transport of cells, nutrients, waste, and therapies through tissues; and can be engineered from autologous cell sources.

OOC platforms can mimic the immune-tumor cell crosstalk found in the CRC TME. For example, Parlato et al. monitored the interactions between untreated and treated CRC tumor cells 
and interferon- $\alpha$-conditioned dendritic cells (IFN-DCs)-a potential cancer therapeutic with the ability to uptake cancer antigens, stimulate a $\mathrm{T}$ cell response, and phagocytose tumor cells-in a 3D microfluidic model (Figure 1B). They observed that IFN-DCs preferentially migrate towards and phagocytose tumor cells that have been treated with interferon- $\alpha$ and romidepsin, thereby demonstrating the utility of the model for tracking immune-tumor cell interactions in real time and examining novel combination therapies. In a series of papers, an interdisciplinary team reported that patient- and murinederived organotypic tumor spheroids cultured in microfluidic devices retain the tumor, stromal, and immune cell populations for multiple cancers, including CRC (107-109). The team also demonstrated that this model system recreates the tumor response to checkpoint blockade therapy more accurately than $3 \mathrm{D}$ in vitro systems and can be used to screen novel therapeutics for efficacy. A 2020 report from our group probed the role of M1 and M2 macrophages in the TME using a vascularized CRC OOC model (39) (Figure 1C). Our results showed that M1 macrophages inhibit angiogenesis and tumor cell growth and migration, while M2 macrophages have the reverse effect. Further, we showed that these outcomes are mediated by macrophage-derived soluble factors, suggesting new therapeutic targets and demonstrating the utility of the OOC platform to characterize the CRC TME.

\section{FUTURE DIRECTIONS}

Improvement of CRC and CRLM patient outcomes requires the development of efficacious, targeted therapies. Immunemediated therapeutic strategies are particularly promising but remain unrealized, which can be partially attributed to the inability of current in vitro and in vivo models to fully recapitulate immunity in the TME. $2 \mathrm{D}$ culture experiments provide an informative picture of tumor-immune cell crosstalk, but are limited in the number of cell types that can be examined simultaneously and cannot mimic in vivo transport of cells and secreted factors. 3D culture systems can support multiple cell types, mimic transport of biochemical factors through tumor tissue, and reproduce tumor response to immunotherapy, but lack the vascular supply necessary to mimic in vivo transport of immune cells to and through the tumor. Murine models have been critical to characterizing the immunobiology of the CRC TME, but these models struggle to accurately recapitulate

\section{REFERENCES}

1. Siegel RL, Miller KD, Goding Sauer A, Fedewa SA, Butterly LF, Anderson JC, et al. Colorectal cancer statistics, 2020. CA Cancer J Clin (2020) 70 (3):145-64. doi: 10.3322/caac.21601

2. Dekker E, Tanis PJ, Vleugels JLA, Kasi PM, Wallace MB. Colorectal cancer. Lancet (2019) 394(10207):1467-80. doi: 10.1016/S0140-6736(19)32319-0

3. Chow FC, Chok KS. Colorectal liver metastases: An update on multidisciplinary approach. World J Hepatol (2019) 11(2):150-72. doi: 10.4254/wih.v11.i2.150 metastasis; further, successful transition of therapeutics from murine studies to clinical practice remains quite limited. OOC platforms are capable of recapitulating the CRC TME, characterizing tumor-immune cell crosstalk, and mimicking patient-specific tumor response to therapy, but remain limited in their ability to model metastasis.

In contrast to the extensively characterized and utilized $2 \mathrm{D}$ culture, 3D culture, and mouse model systems, OOC platforms remain in early-stage development with untapped potential. Future work with OOC technology should focus on recreating colon-specific biological and physiochemical features of the primary CRC and metastatic CRLM TME. In particular, these models should seek to: i) incorporate tumor, stromal, and immune cells at the ratios found in the native TME; ii) mimic both MSS and MSI-H tumors; iii) utilize patient-specific cell sources; and iv) recreate the metastatic cascade by connecting CRC tissue models to liver tissue models using microfluidics. These advances in experimental modeling, especially when coupled with unforeseen progress, will produce additional knowledge regarding immunity in the CRC and CRLM TMEs and tumor response to immunotherapies, which may inform future clinical strategies and patient outcomes.

\section{AUTHOR CONTRIBUTIONS}

PSY, NDP, VSS, and YP performed the literature review. PSY and NDP wrote the manuscript. VSS, YP, AK, RJC, RCF, SCG, and SG critically reviewed and edited the manuscript. YP, VSS, and NDP created the figure. PSY compiled the table. RCF, SCG, and SG received the funding sources. All authors contributed to the article and approved the submitted version.

\section{FUNDING}

This work is supported in part by grants from the National Institutes of Health (R21 CA223836, Fields and George), the Cancer Research Coordinating Committee (CRCC, University of California System, Gholami and George).

\section{ACKNOWLEDGMENTS}

Figure 1 was created with Biorender.com.

4. Misiakos EP, Karidis NP, Kouraklis G. Current treatment for colorectal liver metastases. World J Gastroenterol (2011) 17(36):4067-75. doi: 10.3748/ wjg.v17.i36.4067

5. Pathak S, Jones R, Tang JM, Parmar C, Fenwick S, Malik H, et al. Ablative therapies for colorectal liver metastases: a systematic review. Colorectal Dis (2011) 13(9):e252-65. doi: 10.1111/j.1463-1318.2011.02695.x

6. Katz SC, Pillarisetty V, Bamboat ZM, Shia J, Hedvat C, Gonen M, et al. T cell infiltrate predicts long-term survival following resection of colorectal cancer liver metastases. Ann Surg Oncol (2009) 16(9):2524-30. doi: 10.1245/ s10434-009-0585-3 
7. Pages F, Galon J, Dieu-Nosjean MC, Tartour E, Sautes-Fridman C, Fridman WH. Immune infiltration in human tumors: a prognostic factor that should not be ignored. Oncogene (2010) 29(8):1093-102. doi: 10.1038/onc.2009.416

8. Maker AV, Ito H, Mo Q, Weisenberg E, Qin LX, Turcotte S, et al. Genetic evidence that intratumoral T-cell proliferation and activation are associated with recurrence and survival in patients with resected colorectal liver metastases. Cancer Immunol Res (2015) 3(4):380-8. doi: 10.1158/2326-6066.CIR-14-0212

9. Mlecnik B, Tosolini M, Kirilovsky A, Berger A, Bindea G, Meatchi T, et al. Histopathologic-based prognostic factors of colorectal cancers are associated with the state of the local immune reaction. J Clin Oncol (2011) 29(6):610-8. doi: 10.1200/JCO.2010.30.5425

10. Donadon M, Hudspeth K, Cimino M, Di Tommaso L, Preti M, Tentorio P, et al. Increased Infiltration of Natural Killer and T Cells in Colorectal Liver Metastases Improves Patient Overall Survival. J Gastrointest Surg (2017) 21 (8):1226-36. doi: 10.1007/s11605-017-3446-6

11. Nakagawa K, Tanaka K, Homma Y, Nojiri K, Kumamoto T, Takeda K, et al. Low infiltration of peritumoral regulatory $\mathrm{T}$ cells predicts worse outcome following resection of colorectal liver metastases. Ann Surg Oncol (2015) 22 (1):180-6. doi: 10.1245/s10434-014-3974-1

12. Grossman JG, Nywening TM, Belt BA, Panni RZ, Krasnick BA, DeNardo DG, et al. Recruitment of CCR2(+) tumor associated macrophage to sites of liver metastasis confers a poor prognosis in human colorectal cancer. Oncoimmunology (2018) 7(9):e1470729. doi: 10.1080/2162402X.2018.1470729

13. Forssell J, Oberg A, Henriksson ML, Stenling R, Jung A, Palmqvist R. High macrophage infiltration along the tumor front correlates with improved survival in colon cancer. Clin Cancer Res (2007) 13(5):1472-9. doi: 10.1158/ 1078-0432.CCR-06-2073

14. Cavnar MJ, Turcotte S, Katz SC, Kuk D, Gonen M, Shia J, et al. TumorAssociated Macrophage Infiltration in Colorectal Cancer Liver Metastases is Associated With Better Outcome. Ann Surg Oncol (2017) 24(7):1835-42. doi: 10.1245/s10434-017-5812-8

15. Zhou Q, Peng RQ, Wu XJ, Xia Q, Hou JH, Ding Y, et al. The density of macrophages in the invasive front is inversely correlated to liver metastasis in colon cancer. J Transl Med (2010) 8:13. doi: 10.1186/1479-5876-8-13

16. Galon J, Costes A, Sanchez-Cabo F, Kirilovsky A, Mlecnik B, Lagorce-Pages $\mathrm{C}$, et al. Type, density, and location of immune cells within human colorectal tumors predict clinical outcome. Science (2006) 313(5795):1960-4. doi: 10.1126/science.1129139

17. Galon J, Pages F, Marincola FM, Thurin M, Trinchieri G, Fox BA, et al. The immune score as a new possible approach for the classification of cancer. J Transl Med (2012) 10:1. doi: 10.1186/1479-5876-10-1

18. Pages F, Mlecnik B, Marliot F, Bindea G, Ou FS, Bifulco C, et al. International validation of the consensus Immunoscore for the classification of colon cancer: a prognostic and accuracy study. Lancet (2018) 391(10135):2128-39. doi: 10.1016/S0140-6736(18)30789-X

19. Ganesh K, Stadler ZK, Cercek A, Mendelsohn RB, Shia J, Segal NH, et al. Immunotherapy in colorectal cancer: rationale, challenges and potential. Nat Rev Gastroenterol Hepatol (2019) 16(6):361-75. doi: 10.1038/s41575-019-0126-x

20. Kalyan A, Kircher S, Shah H, Mulcahy M, Benson A. Updates on immunotherapy for colorectal cancer. J Gastrointest Oncol (2018) 9 (1):160-9. doi: 10.21037/jgo.2018.01.17

21. Tintelnot J, Stein A. Immunotherapy in colorectal cancer: Available clinical evidence, challenges and novel approaches. World J Gastroenterol (2019) 25 (29):3920-8. doi: 10.3748/wjg.v25.i29.3920

22. Le DT, Uram JN, Wang H, Bartlett BR, Kemberling H, Eyring AD, et al. PD1 Blockade in Tumors with Mismatch-Repair Deficiency. $N$ Engl J Med (2015) 372(26):2509-20. doi: 10.1056/NEJMoa1500596

23. Overman MJ, Lonardi S, Wong KYM, Lenz HJ, Gelsomino F, Aglietta M, et al. Durable Clinical Benefit With Nivolumab Plus Ipilimumab in DNA Mismatch Repair-Deficient/Microsatellite Instability-High Metastatic Colorectal Cancer. J Clin Oncol (2018) 36(8):773-9. doi: 10.1200/JCO.2017.76.9901

24. Hachey SJ, Hughes CCW. Applications of tumor chip technology. Lab Chip (2018) 18(19):2893-912. doi: 10.1039/C8LC00330K

25. Stock K, Estrada MF, Vidic S, Gjerde K, Rudisch A, Santo VE, et al. Capturing tumor complexity in vitro: Comparative analysis of $2 \mathrm{D}$ and $3 \mathrm{D}$ tumor models for drug discovery. Sci Rep (2016) 6:28951. doi: 10.1038/ srep 28951
26. Kumar V, Varghese S. Ex Vivo Tumor-on-a-Chip Platforms to Study Intercellular Interactions within the Tumor Microenvironment. Adv Healthc Mater (2019) 8(4):e1801198. doi: 10.1002/adhm.201801198

27. Binnewies M, Roberts EW, Kersten K, Chan V, Fearon DF, Merad M, et al. Understanding the tumor immune microenvironment (TIME) for effective therapy. Nat Med (2018) 24(5):541-50. doi: 10.1038/s41591-018-0014-x

28. Edmondson R, Broglie JJ, Adcock AF, Yang L. Three-dimensional cell culture systems and their applications in drug discovery and cell-based biosensors. Assay Drug Dev Technol (2014) 12(4):207-18. doi: 10.1089/ adt. 2014.573

29. Asghar W, El Assal R, Shafiee H, Pitteri S, Paulmurugan R, Demirci U. Engineering cancer microenvironments for in vitro 3-D tumor models. Mater Today (Kidlington) (2015) 18(10):539-53. doi: 10.1016/ j.mattod.2015.05.002

30. Duval K, Grover H, Han LH, Mou Y, Pegoraro AF, Fredberg J, et al. Modeling Physiological Events in 2D vs. 3D Cell Culture. Physiology (Bethesda) (2017) 32(4):266-77. doi: 10.1152/physiol.00036.2016

31. Kapałczyńska M, Kolenda T, Przybyła W, Zajączkowska M, Teresiak A, Filas V, et al. 2D and 3D cell cultures - a comparison of different types of cancer cell cultures. Arch Med Sci (2018) 14(4):910-9. doi: 10.5114/aoms.2016.63743

32. Mestas J, Hughes CC. Of mice and not men: differences between mouse and human immunology. J Immunol (2004) 172(5):2731-8. doi: 10.4049/ jimmunol.172.5.2731

33. Frese KK, Tuveson DA. Maximizing mouse cancer models. Nat Rev Cancer (2007) 7(9):645-58. doi: 10.1038/nrc2192

34. Guerin MV, Finisguerra V, Van den Eynde BJ, Bercovici N, Trautmann A. Preclinical murine tumor models: a structural and functional perspective. Elife (2020) 9:e50740. doi: 10.7554/eLife.50740

35. Caballero D, Kaushik S, Correlo VM, Oliveira JM, Reis RL, Kundu SC. Organ-on-chip models of cancer metastasis for future personalized medicine: From chip to the patient. Biomaterials (2017) 149:98-115. doi: 10.1016/j.biomaterials.2017.10.005

36. Huang YL, Segall JE, Wu M. Microfluidic modeling of the biophysical microenvironment in tumor cell invasion. Lab Chip (2017) 17(19):3221-33. doi: 10.1039/C7LC00623C

37. Heylman C, Sobrino A, Shirure VS, Hughes CC, George SC. A strategy for integrating essential three-dimensional microphysiological systems of human organs for realistic anticancer drug screening. Exp Biol Med (Maywood) (2014) 239(9):1240-54. doi: 10.1177/1535370214525295

38. Parlato S, De Ninno A, Molfetta R, Toschi E, Salerno D, Mencattini A, et al. 3D Microfluidic model for evaluating immunotherapy efficacy by tracking dendritic cell behaviour toward tumor cells. Sci Rep (2017) 7(1):1093. doi: 10.1038/s41598-017-01013-X

39. Bi Y, Shirure VS, Liu R, Cunningham C, Ding L, Meacham JM, et al. Tumoron-a-chip platform to interrogate the role of macrophages in tumor progression. Integr Biol (Camb) (2020) 12(9):221-32. doi: 10.1101/ 2020.05.27.119636

40. Pouliot N, Connolly LM, Moritz RL, Simpson RJ, Burgess AW. Colon cancer cells adhesion and spreading on autocrine laminin-10 is mediated by multiple integrin receptors and modulated by EGF receptor stimulation. Exp Cell Res (2000) 261(2):360-71. doi: 10.1006/excr.2000.5065

41. Bartolomé RA, Barderas R, Torres S, Fernandez-Aceñero MJ, Mendes M, García-Foncillas J, et al. Cadherin-17 interacts with $\alpha 2 \beta 1$ integrin to regulate cell proliferation and adhesion in colorectal cancer cells causing liver metastasis. Oncogene (2014) 33(13):1658-69. doi: 10.1038/onc.2013.117

42. Barbazan J, Alonso-Alconada L, Elkhatib N, Geraldo S, Gurchenkov V, Glentis A, et al. Liver Metastasis Is Facilitated by the Adherence of Circulating Tumor Cells to Vascular Fibronectin Deposits. Cancer Res (2017) 77(13):3431-41. doi: 10.1158/0008-5472.CAN-16-1917

43. Wang H, Wang HS, Zhou BH, Li CL, Zhang F, Wang XF, et al. Epithelialmesenchymal transition (EMT) induced by TNF- $\alpha$ requires AKT/GSK-3 $\beta$ mediated stabilization of snail in colorectal cancer. PloS One (2013) 8(2): e56664. doi: 10.1371/journal.pone.0056664

44. Kahlert C, Lahes S, Radhakrishnan P, Dutta S, Mogler C, Herpel E, et al. Overexpression of ZEB2 at the invasion front of colorectal cancer is an independent prognostic marker and regulates tumor invasion in vitro. Clin Cancer Res (2011) 17(24):7654-63. doi: 10.1158/1078-0432.CCR-10-2816 
45. Deng JJ, Zhang W, Xu XM, Zhang F, Tao WP, Ye JJ, et al. Twist mediates an aggressive phenotype in human colorectal cancer cells. Int J Oncol (2016) 48 (3):1117-24. doi: 10.3892/ijo.2016.3342

46. Jackstadt R, Röh S, Neumann J, Jung P, Hoffmann R, Horst D, et al. AP4 is a mediator of epithelial-mesenchymal transition and metastasis in colorectal cancer. J Exp Med (2013) 210(7):1331-50. doi: 10.1084/jem.20120812

47. Han X, Fang X, Lou X, Hua D, Ding W, Foltz G, et al. Silencing SOX2 induced mesenchymal-epithelial transition and its expression predicts liver and lymph node metastasis of CRC patients. PloS One (2012) 7(8):e41335. doi: 10.1371/journal.pone.0041335

48. Dai X, Ge J, Wang X, Qian X, Zhang C, Li X. OCT4 regulates epithelialmesenchymal transition and its knockdown inhibits colorectal cancer cell migration and invasion. Oncol Rep (2013) 29(1):155-60. doi: 10.3892/ or.2012.2086

49. Cui YM, Jiao HL, Ye YP, Chen CM, Wang JX, Tang N, et al. FOXC2 promotes colorectal cancer metastasis by directly targeting MET. Oncogene (2015) 34(33):4379-90. doi: 10.1038/onc.2014.368

50. Bartolome RA, Pintado-Berninches L, Jaen M, de Los Rios V, Imbaud JI, Casal JI. SOSTDC1 promotes invasion and liver metastasis in colorectal cancer via interaction with ALCAM/CD166. Oncogene (2020) 39(38):608598. doi: 10.1038/s41388-020-01419-4

51. Lundholm M, Hagglof C, Wikberg ML, Stattin P, Egevad L, Bergh A, et al. Secreted Factors from Colorectal and Prostate Cancer Cells Skew the Immune Response in Opposite Directions. Sci Rep (2015) 5:15651. doi: $10.1038 /$ srep 15651

52. Edin S, Wikberg ML, Rutegard J, Oldenborg PA, Palmqvist R. Phenotypic skewing of macrophages in vitro by secreted factors from colorectal cancer cells. PloS One (2013) 8(9):e74982. doi: 10.1371/journal.pone.0074982

53. Patel SA, Gooderham NJ. IL6 Mediates Immune and Colorectal Cancer Cell Cross-talk via miR-21 and miR-29b. Mol Cancer Res (2015) 13(11):1502-8. doi: 10.1158/1541-7786.MCR-15-0147

54. Zhang Y, Sime W, Juhas M, Sjolander A. Crosstalk between colon cancer cells and macrophages via inflammatory mediators and CD47 promotes tumour cell migration. Eur J Cancer (2013) 49(15):3320-34. doi: 10.1016/ j.ejca.2013.06.005

55. Wei C, Yang C, Wang S, Shi D, Zhang C, Lin X, et al. Crosstalk between cancer cells and tumor associated macrophages is required for mesenchymal circulating tumor cell-mediated colorectal cancer metastasis. Mol Cancer (2019) 18(1):64. doi: 10.1186/s12943-019-0976-4

56. Kaminski BM, Weigert A, Scherzberg MC, Ley S, Gilbert B, Brecht K, et al. Resveratrol-induced potentiation of the antitumor effects of oxaliplatin is accompanied by an altered cytokine profile of human monocyte-derived macrophages. Apoptosis (2014) 19(7):1136-47. doi: 10.1007/s10495-0140988-X

57. Yin $\mathrm{Y}, \mathrm{Yao} \mathrm{S}, \mathrm{Hu} \mathrm{Y}$, Feng $\mathrm{Y}$, Li M, Bian Z, et al. The Immunemicroenvironment Confers Chemoresistance of Colorectal Cancer through Macrophage-Derived IL6. Clin Cancer Res (2017) 23(23):737587. doi: 10.1158/1078-0432.CCR-17-1283

58. Yu Y, Blokhuis B, Derks Y, Kumari S, Garssen J, Redegeld F. Human mast cells promote colon cancer growth via bidirectional crosstalk: studies in $2 \mathrm{D}$ and 3D coculture models. Oncoimmunology (2018) 7(11):e1504729. doi: 10.1080/2162402X.2018.1504729

59. Casati C, Dalerba P, Rivoltini L, Gallino G, Deho P, Rini F, et al. The apoptosis inhibitor protein survivin induces tumor-specific CD8+ and CD4+ $\mathrm{T}$ cells in colorectal cancer patients. Cancer Res (2003) 63(15):4507-15.

60. Turin I, Delfanti S, Ferulli F, Brugnatelli S, Tanzi M, Maestri M, et al. In Vitro Killing of Colorectal Carcinoma Cells by Autologous Activated NK Cells is Boosted by Anti-Epidermal Growth Factor Receptor-induced ADCC Regardless of RAS Mutation Status. J Immunother (2018) 41(4):190-200. doi: 10.1097/CJI.0000000000000205

61. Hirt C, Papadimitropoulos A, Muraro MG, Mele V, Panopoulos E, Cremonesi E, et al. Bioreactor-engineered cancer tissue-like structures mimic phenotypes, gene expression profiles and drug resistance patterns observed "in vivo". Biomaterials (2015) 62:138-46. doi: 10.1016/ j.biomaterials.2015.05.037

62. Devarasetty M, Dominijanni A, Herberg S, Shelkey E, Skardal A, Soker S. Simulating the human colorectal cancer microenvironment in $3 \mathrm{D}$ tumor- stroma co-cultures in vitro and in vivo. Sci Rep (2020) 10(1):9832. doi: 10.1038/s41598-020-66785-1

63. Tsunoda T, Takashima Y, Yoshida Y, Doi K, Tanaka Y, Fujimoto T, et al. Oncogenic KRAS regulates miR-200c and miR-221/222 in a 3D-specific manner in colorectal cancer cells. Anticancer Res (2011) 31(7):2453-9.

64. Zoetemelk M, Rausch M, Colin DJ, Dormond O, Nowak-Sliwinska P. Shortterm $3 \mathrm{D}$ culture systems of various complexity for treatment optimization of colorectal carcinoma. Sci Rep (2019) 9(1):7103. doi: 10.1038/s41598-01942836-0

65. Stankevicius V, Vasauskas G, Noreikiene R, Kuodyte K, Valius M, Suziedelis K. Extracellular Matrix-dependent Pathways in Colorectal Cancer Cell Lines Reveal Potential Targets for Anticancer Therapies. Anticancer Res (2016) 36 (9):4559-67. doi: 10.21873/anticanres.11004

66. Luca AC, Mersch S, Deenen R, Schmidt S, Messner I, Schäfer KL, et al. Impact of the $3 \mathrm{D}$ microenvironment on phenotype, gene expression, and EGFR inhibition of colorectal cancer cell lines. PloS One (2013) 8(3):e59689. doi: 10.1371/journal.pone.0059689

67. Devarasetty M, Wang E, Soker S, Skardal A. Mesenchymal stem cells support growth and organization of host-liver colorectal-tumor organoids and possibly resistance to chemotherapy. Biofabrication (2017) 9(2):021002. doi: 10.1088/1758-5090/aa7484

68. Wan X, Li Z, Ye H, Cui Z. Three-dimensional perfused tumour spheroid model for anti-cancer drug screening. Biotechnol Lett (2016) 38(8):1389-95. doi: 10.1007/s10529-016-2035-1

69. Manfredonia C, Muraro MG, Hirt C, Mele V, Governa V, Papadimitropoulos A, et al. Maintenance of Primary Human Colorectal Cancer Microenvironment Using a Perfusion Bioreactor-Based 3D Culture System. Adv Biosyst (2019) 3(4):e1800300. doi: 10.1002/adbi.201800300

70. Fang Y, Eglen RM. Three-Dimensional Cell Cultures in Drug Discovery and Development. SLAS Discov (2017) 22(5):456-72. doi: 10.1177/ 1087057117696795

71. Dijkstra KK, Cattaneo CM, Weeber F, Chalabi M, van de Haar J, Fanchi LF, et al. Generation of Tumor-Reactive T Cells by Co-culture of Peripheral Blood Lymphocytes and Tumor Organoids. Cell (2018) 174(6):1586-98.e12. doi: 10.1016/j.cell.2018.07.009

72. Courau T, Bonnereau J, Chicoteau J, Bottois H, Remark R, Assante Miranda $\mathrm{L}$, et al. Cocultures of human colorectal tumor spheroids with immune cells reveal the therapeutic potential of MICA/B and NKG2A targeting for cancer treatment. J Immunother Cancer (2019) 7(1):74. doi: 10.1186/s40425-0190553-9

73. Schnalzger TE, de Groot MH, Zhang C, Mosa MH, Michels BE, Roder J, et al. 3D model for CAR-mediated cytotoxicity using patient-derived colorectal cancer organoids. EMBO J (2019) 38(12):e100928. doi: 10.15252/embj.2018100928

74. Morton JJ, Bird G, Refaeli Y, Jimeno A. Humanized Mouse Xenograft Models: Narrowing the Tumor-Microenvironment Gap. Cancer Res (2016) 76(21):6153-8. doi: 10.1158/0008-5472.CAN-16-1260

75. Kersten K, de Visser KE, van Miltenburg MH, Jonkers J. Genetically engineered mouse models in oncology research and cancer medicine. EMBO Mol Med (2017) 9(2):137-53. doi: 10.15252/emmm.201606857

76. Yoshida GJ. Applications of patient-derived tumor xenograft models and tumor organoids. J Hematol Oncol (2020) 13(1):4. doi: 10.1186/s13045-019$0829-z$

77. Izumchenko E, Paz K, Ciznadija D, Sloma I, Katz A, Vasquez-Dunddel D, et al. Patient-derived xenografts effectively capture responses to oncology therapy in a heterogeneous cohort of patients with solid tumors. Ann Oncol (2017) 28(10):2595-605. doi: 10.1093/annonc/mdx416

78. Morton CL, Houghton PJ. Establishment of human tumor xenografts in immunodeficient mice. Nat Protoc (2007) 2(2):247-50. doi: 10.1038/ nprot.2007.25

79. Zhong W, Myers JS, Wang F, Wang K, Lucas J, Rosfjord E, et al. Comparison of the molecular and cellular phenotypes of common mouse syngeneic models with human tumors. BMC Genomics (2020) 21(1):2. doi: 10.1186 s12864-019-6344-3

80. Bertotti A, Migliardi G, Galimi F, Sassi F, Torti D, Isella C, et al. A molecularly annotated platform of patient-derived xenografts ("xenopatients") identifies HER2 as an effective therapeutic target in 
cetuximab-resistant colorectal cancer. Cancer Discov (2011) 1(6):508-23. doi: 10.1158/2159-8290.CD-11-0109

81. Kavuri SM, Jain N, Galimi F, Cottino F, Leto SM, Migliardi G, et al. HER2 activating mutations are targets for colorectal cancer treatment. Cancer Discov (2015) 5(8):832-41. doi: 10.1158/2159-8290.CD-14-1211

82. Nunes $M$, Vrignaud $P$, Vacher S, Richon S, Lièvre A, Cacheux W, et al. Evaluating patient-derived colorectal cancer xenografts as preclinical models by comparison with patient clinical data. Cancer Res (2015) 75(8):1560-6. doi: 10.1158/0008-5472.CAN-14-1590

83. Zanella ER, Galimi F, Sassi F, Migliardi G, Cottino F, Leto SM, et al. IGF2 is an actionable target that identifies a distinct subpopulation of colorectal cancer patients with marginal response to anti-EGFR therapies. Sci Transl Med (2015) 7(272):272ra12. doi: 10.1126/scitranslmed.3010445

84. Bardelli A, Corso S, Bertotti A, Hobor S, Valtorta E, Siravegna G, et al. Amplification of the MET receptor drives resistance to anti-EGFR therapies in colorectal cancer. Cancer Discov (2013) 3(6):658-73. doi: 10.1158/21598290.CD-12-0558

85. Hung KE, Maricevich MA, Richard LG, Chen WY, Richardson MP, Kunin A, et al. Development of a mouse model for sporadic and metastatic colon tumors and its use in assessing drug treatment. Proc Natl Acad Sci U S A (2010) 107(4):1565-70. doi: 10.1073/pnas.0908682107

86. Coffee EM, Faber AC, Roper J, Sinnamon MJ, Goel G, Keung L, et al. Concomitant BRAF and PI3K/mTOR blockade is required for effective treatment of BRAF(V600E) colorectal cancer. Clin Cancer Res (2013) 19 (10):2688-98. doi: 10.1158/1078-0432.CCR-12-2556

87. Tauriello DVF, Palomo-Ponce S, Stork D, Berenguer-Llergo A, BadiaRamentol J, Iglesias $\mathrm{M}$, et al. TGF $\beta$ drives immune evasion in genetically reconstituted colon cancer metastasis. Nature (2018) 554(7693):538-43. doi: 10.1038/nature25492

88. Boutin AT, Liao WT, Wang M, Hwang SS, Karpinets TV, Cheung H, et al. Oncogenic Kras drives invasion and maintains metastases in colorectal cancer. Genes Dev (2017) 31(4):370-82. doi: 10.1101/gad.293449.116

89. Burtin F, Mullins CS, Linnebacher M. Mouse models of colorectal cancer: Past, present and future perspectives. World J Gastroenterol (2020) 26 (13):1394-426. doi: 10.3748/wjg.v26.i13.1394

90. Romano G, Chagani S, Kwong LN. The path to metastatic mouse models of colorectal cancer. Oncogene (2018) 37(19):2481-9. doi: 10.1038/s41388-018-0155-x

91. Ishikawa F, Yasukawa M, Lyons B, Yoshida S, Miyamoto T, Yoshimoto G, et al. Development of functional human blood and immune systems in NOD/SCID/IL2 receptor \{gamma\} chain(null) mice. Blood (2005) 106 (5):1565-73. doi: 10.1182/blood-2005-02-0516

92. Humanized Mice Services. Bar Harbor, ME: The Jackson Laboratory. Available at: https://www.jax.org/jax-mice-and-services/in-vivo-pharmacology/humanizedmice\#.

93. Sanmamed MF, Rodriguez I, Schalper KA, Onate C, Azpilikueta A, Rodriguez-Ruiz ME, et al. Nivolumab and Urelumab Enhance Antitumor Activity of Human T Lymphocytes Engrafted in Rag2-/-IL2Rgammanull Immunodeficient Mice. Cancer Res (2015) 75(17):3466-78. doi: 10.1158/ 0008-5472.CAN-14-3510

94. Capasso A, Lang J, Pitts TM, Jordan KR, Lieu CH, Davis SL, et al. Characterization of immune responses to anti-PD-1 mono and combination immunotherapy in hematopoietic humanized mice implanted with tumor xenografts. J Immunother Cancer (2019) 7(1):37. doi: 10.1186/s40425-019-0518-z

95. Oh BY, Hong HK, Lee WY, Cho YB. Animal models of colorectal cancer with liver metastasis. Cancer Lett (2017) 387:114-20. doi: 10.1016/ j.canlet.2016.01.048

96. Kostic AD, Chun E, Robertson L, Glickman JN, Gallini CA, Michaud M, et al. Fusobacterium nucleatum potentiates intestinal tumorigenesis and modulates the tumor-immune microenvironment. Cell Host Microbe (2013) 14(2):207-15. doi: 10.1016/j.chom.2013.07.007

97. Schwitalla S, Ziegler PK, Horst D, Becker V, Kerle I, Begus-Nahrmann Y, et al. Loss of p53 in enterocytes generates an inflammatory microenvironment enabling invasion and lymph node metastasis of carcinogen-induced colorectal tumors. Cancer Cell (2013) 23(1):93-106. doi: 10.1016/j.ccr.2012.11.014

98. Grivennikov S, Karin E, Terzic J, Mucida D, Yu GY, Vallabhapurapu S, et al. IL-6 and Stat 3 are required for survival of intestinal epithelial cells and development of colitis-associated cancer. Cancer Cell (2009) 15(2):103-13. doi: 10.1016/j.ccr.2009.01.001
99. Fukata M, Chen A, Vamadevan AS, Cohen J, Breglio K, Krishnareddy S, et al. Toll-like receptor-4 promotes the development of colitis-associated colorectal tumors. Gastroenterology (2007) 133(6):1869-81. doi: 10.1053/ j.gastro.2007.09.008

100. Allen IC, TeKippe EM, Woodford RM, Uronis JM, Holl EK, Rogers AB, et al. The NLRP3 inflammasome functions as a negative regulator of tumorigenesis during colitis-associated cancer. J Exp Med (2010) 207 (5):1045-56. doi: 10.1084/jem.20100050

101. Chen GY, Shaw MH, Redondo G, Nunez G. The innate immune receptor Nod1 protects the intestine from inflammation-induced tumorigenesis. Cancer Res (2008) 68(24):10060-7. doi: 10.1158/0008-5472.CAN-08-2061

102. Low LA, Mummery C, Berridge BR, Austin CP, Tagle DA. Organs-on-chips: into the next decade. Nat Rev Drug Discov (2020). doi: 10.1038/s41573-020-0079-3

103. Shirure VS, Bi Y, Curtis MB, Lezia A, Goedegebuure MM, Goedegebuure SP, et al. Tumor-on-a-chip platform to investigate progression and drug sensitivity in cell lines and patient-derived organoids. Lab Chip (2018) 18 (23):3687-702. doi: 10.1039/C8LC00596F

104. Jeong SY, Lee JH, Shin Y, Chung S, Kuh HJ. Co-Culture of Tumor Spheroids and Fibroblasts in a Collagen Matrix-Incorporated Microfluidic Chip Mimics Reciprocal Activation in Solid Tumor Microenvironment. PloS One (2016) 11(7):e0159013. doi: 10.1371/journal.pone.0159013

105. Carvalho MR, Barata D, Teixeira LM, Giselbrecht S, Reis RL, Oliveira JM, et al. Colorectal tumor-on-a-chip system: A 3D tool for precision onconanomedicine. Sci Adv (2019) 5(5):eaaw1317. doi: 10.1126/sciadv.aaw1317

106. Sobrino A, Phan DT, Datta R, Wang X, Hachey SJ, Romero-López M, et al. 3D microtumors in vitro supported by perfused vascular networks. Sci Rep (2016) 6:31589. doi: 10.1038/srep31589

107. Aref AR, Campisi M, Ivanova E, Portell A, Larios D, Piel BP, et al. 3D microfluidic ex vivo culture of organotypic tumor spheroids to model immune checkpoint blockade. Lab Chip (2018) 18(20):3129-43. doi: 10.1039/C8LC00322J

108. Deng J, Wang ES, Jenkins RW, Li S, Dries R, Yates K, et al. CDK4/6 Inhibition Augments Antitumor Immunity by Enhancing T-cell Activation. Cancer Discov (2018) 8(2):216-33. doi: 10.1158/21598290.CD-17-0915

109. Jenkins RW, Aref AR, Lizotte PH, Ivanova E, Stinson S, Zhou CW, et al. Ex Vivo Profiling of PD-1 Blockade Using Organotypic Tumor Spheroids. Cancer Discov (2018) 8(2):196-215. doi: 10.1158/2159-8290.CD-17-0833

110. Skardal A, Devarasetty M, Forsythe S, Atala A, Soker S. A reductionist metastasis-on-a-chip platform for in vitro tumor progression modeling and drug screening. Biotechnol Bioeng (2016) 113(9):2020-32. doi: 10.1002/ bit. 25950

111. Aleman J, Skardal A. A multi-site metastasis-on-a-chip microphysiological system for assessing metastatic preference of cancer cells. Biotechnol Bioeng (2019) 116(4):936-44. doi: 10.1002/bit.26871

112. Sung JH, Shuler ML. A micro cell culture analog (microCCA) with 3-D hydrogel culture of multiple cell lines to assess metabolism-dependent cytotoxicity of anti-cancer drugs. Lab Chip (2009) 9(10):1385-94. doi: $10.1039 / \mathrm{b} 901377 \mathrm{f}$

113. Weng KC, Kurokawa YK, Hajek BS, Paladin JA, Shirure VS, George SC. Human Induced Pluripotent Stem-Cardiac-Endothelial-Tumor-on-a-Chip to Assess Anticancer Efficacy and Cardiotoxicity. Tissue Eng Part C Methods (2020) 26(1):44-55. doi: 10.1089/ten.tec.2019.0248

114. Oudin MJ, Weaver VM. Physical and Chemical Gradients in the Tumor Microenvironment Regulate Tumor Cell Invasion, Migration, and Metastasis. Cold Spring Harb Symp Quant Biol (2016) 81:189-205. doi: 10.1101/sqb.2016.81.030817

115. Shirure VS, Lezia A, Tao A, Alonzo LF, George SC. Low levels of physiological interstitial flow eliminate morphogen gradients and guide angiogenesis. Angiogenesis (2017) 20(4):493-504. doi: 10.1007/s10456-017-9559-4

116. Hwang PY, Brenot A, King AC, Longmore GD, George SC. Randomly Distributed K14(+) Breast Tumor Cells Polarize to the Leading Edge and Guide Collective Migration in Response to Chemical and Mechanical Environmental Cues. Cancer Res (2019) 79(8):1899-912. doi: 10.1158/ 0008-5472.CAN-18-2828

117. Lam SF, Shirure VS, Chu YE, Soetikno AG, George SC. Microfluidic device to attain high spatial and temporal control of oxygen. PloS One (2018) 13(12): e0209574. doi: 10.1371/journal.pone.0209574 
118. Shirure VS, Lam SF, Shergill B, Chu YE, Ng NR, George SC. Quantitative design strategies for fine control of oxygen in microfluidic systems. Lab Chip (2020) 20(16):3036-50. doi: 10.1039/D0LC00350F

119. Semenza GL. Hypoxia-inducible factors in physiology and medicine. Cell (2012) 148(3):399-408. doi: 10.1016/j.cell.2012.01.021

120. Taylor CT, Colgan SP. Regulation of immunity and inflammation by hypoxia in immunological niches. Nat Rev Immunol (2017) 17(12):774-85. doi: 10.1038/nri.2017.103

121. Moya ML, Alonzo LF, George SC. Microfluidic device to culture 3D in vitro human capillary networks. Methods Mol Biol (2014) 1202:21-7.doi: 10.1007/7651_2013_36

122. Hsu YH, Moya ML, Hughes CC, George SC, Lee AP. A microfluidic platform for generating large-scale nearly identical human microphysiological vascularized tissue arrays. Lab Chip (2013) 13(15):2990-8. doi: 10.1039/c3lc50424g
Conflict of Interest: SCG is co-founder of Aracari Biosciences, a start-up company focused on the commercialization of vascularized OOC technology.

The remaining authors declare that the research was conducted in the absence of any commercial or financial relationships that could be construed as a potential conflict of interest.

Copyright (C) 2021 Yoon, Del Piccolo, Shirure, Peng, Kirane, Canter, Fields, George and Gholami. This is an open-access article distributed under the terms of the Creative Commons Attribution License (CC BY). The use, distribution or reproduction in other forums is permitted, provided the original author(s) and the copyright owner(s) are credited and that the original publication in this journal is cited, in accordance with accepted academic practice. No use, distribution or reproduction is permitted which does not comply with these terms. 